\title{
Małgorzata Czuryk
}

Uniwersytet Warmińsko-Mazurski w Olsztynie

czuryk@interia.pl

\section{Rygory selekcyjne określone w pragmatykach prawa urzędniczego a naruszenie dóbr osobistych osób zatrudnionych na stanowiskach urzędniczych}

\author{
Selection Limits Defined in the Law vs Infringement \\ of Personal Rights of Civil Servants
}

\section{STRESZCZENIE}

Problematyka poruszona w artykule ma na celu wskazanie, że w obowiązującym stanie prawnym wykreowanie przez media krzywdzącego wizerunku osoby publicznej zatrudnionej na stanowisku urzędniczym może przełożyć się na jej stosunek zatrudnienia. Ustawodawca nie wskazał bowiem w pragmatykach urzędniczych żadnych obiektywnych kryteriów, które musiałby zastosować zatrudniający do oceny, czy dana osoba spełnia rygory selekcyjne nieskazitelności charakteru i nieposzlakowanej opinii. Tym samym dobra osobiste pozostają w związku z określonymi rygorami selekcyjnymi. W opracowaniu wskazano podstawowe kategorie dóbr osobistych, których naruszenie może wpływać na postrzeganie osoby publicznej i ocenę spełniania przez nią określonych rygorów selekcyjnych. Zwrócono także uwagę, na czym polega ochrona tych dóbr oraz jakie roszczenia przysługują osobie publicznej, której dobra zostały naruszone i jaki może to mieć wpływ na jej zatrudnienie.

Słowa kluczowe: urzędnik; pracownik; zatrudnienie; rygory selekcyjne; dobra osobiste

\section{WPROWADZENIE}

Jawność działalności administracji publicznej, prawo obywateli do informacji jako przejaw partycypacji społecznej, wolność mediów, a zwłaszcza dostępność współczesnych środków komunikowania - niewłaściwie stosowane mogą prowadzić do negatywnych skutków w wymiarze zatrudnienia pracowniczego. Proble- 
matyka poruszona $\mathrm{w}$ artykule ma na celu wskazanie, że podanie przez dziennikarza w publikacji medialnej niesprawdzonych i nieprawdziwych informacji, przedstawiających daną osobę w negatywnym świetle, może doprowadzić nie tylko do naruszenia jej godności, dobrego imienia, ale i prawa do prywatności. Wykreowanie w mediach tej osoby jako nieposiadającej pożądanych cech (np. do piastowania urzędów publicznych) może bezpośrednio przełożyć się na przyjęcie przez podmiot ją zatrudniający, iż utraciła ona zdolność wykazania się przestrzeganiem wskazanych przez ustawodawcę rygorów selekcyjnych w postaci nieskazitelności charakteru czy nieposzlakowanej opinii. Niestety, w aktualnym stanie prawnym ustawodawca w pragmatykach urzędniczych nie przewidział żadnych obiektywnych kryteriów, które pozwalałyby ocenić zatrudniającemu, czy dany kandydat lub osoba już zatrudniona cieszy się nieposzlakowaną opinią i nieskazitelnym charakterem. Pracodawca posiada w tym zakresie znaczną swobodę dokonania oceny, a możliwości pracownika w zakresie ustosunkowania się do stawianych mu zarzutów nie zostały właściwie zagwarantowane przez ustawodawcę ${ }^{1}$.

\section{RYGORY SELEKCYJNE}

Rygory selekcyjne zostały określone w pragmatykach prawa urzędniczego. Określają one warunki dostępu do służby publicznej w charakterze urzędnika państwowego ${ }^{2}$, do uzyskania statusu członka korpusu służby cywilnej ${ }^{3}$ oraz do zatrudnienia jako pracownik samorządowy ${ }^{4}$. Rygory selekcyjne wskazują warunki, jakie musi spełniać osoba fizyczna ubiegająca się o zatrudnienie na stanowiskach urzędniczych. Rygory selekcyjne nie ograniczają się do kwalifikacji i umiejętności, lecz obejmują także nieposzlakowaną opinię, nieskazitelny charakter i wysokie morale. Oznacza to, że od osób ubiegających się o zatrudnienie na stanowiskach urzędniczych wymaga się odpowiednio wysokich kwalifikacji, również moralnych. Natomiast od chwili zatrudnienia pracownicy zobowiązani są spełniać wymogi określone przez rygory przez cały okres trwania stosunku pracy. Słusznie przyjmuje się, że tylko osoba o nieskazitelnym charakterze czy nieposzlakowanej opinii może dawać rękojmię prawidłowego wykonywania powierzonych jej obowiązków. Skutkiem utraty przymiotów (lub jednego z nich) określonych w pragmatykach prawa urzędniczego będzie ustanie stosunku pracy.

${ }^{1}$ Więcej na ten temat: H. Szewczyk, Stosunki pracy w samorzadzie terytorialnym, Warszawa 2012, s. 95-96.

${ }^{2}$ Ustawa o pracownikach urzędów państwowych z dnia 16 września 1982 r. (t.j. Dz.U. z 2013 r., poz. 269), dalej jako: u.p.u.p.

${ }^{3}$ Ustawa o służbie cywilnej z dnia 21 listopada 2008 r. (t.j. Dz.U. z 2014 r., poz. 1111), dalej jako: u.s.c.

${ }^{4}$ Ustawa o pracownikach samorządowych z dnia 21 listopada 2008 r. (t.j. Dz.U. z 2014 r., poz. 1202), dalej jako: u.p.s. 
Ustawodawca jako rygor selekcyjny, który muszą spełnić członkowie korpusu służby cywilnej i pracownicy samorządowi zatrudnieni na stanowiskach urzędniczych, wskazał nieposzlakowaną opinię . Od urzędników państwowych wymaga się natomiast nieskazitelności charakteru ${ }^{6}$. Pojęcia te, choć podobne, nie są identyczne. Oba mają charakter ocenny i nieostry. Nieposzlakowana opinia to pewien zespół indywidualnych cech, takich jak uczciwość, rzetelność, odpowiedzialność za czyny i słowa, otwartość w stosunku do innych ludzi, skromność i umiarkowanie w życiu codziennym, umiejętność godnego zachowania się w różnych sytuacjach, spolegliwość, uczciwość w życiu prywatnym i rodzinnym ${ }^{7}$. Cechy te wraz ze zdarzeniami i okolicznościami wpływają na wizerunek osoby, której dotyczą. Nieposzlakowana opinia odnosi się przede wszystkim do zachowania urzędnika w życiu zawodowym i publicznym. Jego zachowanie w sferze prywatnej może jednak wyłączyć uznanie, że spełnia on tę cechę, gdyż jego sposób postępowania może wpływać na ocenę wykonywania przez niego obowiązków zawodowych. Wszelkie informacje odnoszące się do zachowania urzędnika (osoby publicznej) w życiu pozazawodowym, które kwestionują dotychczasową pozytywną ocenę postaw moralnych i etycznych tej osoby, naganne w opinii publicznej, mogą zatem bezpośrednio przekładać się na utratę rękojmi prawidłowego wykonywania powierzonej funkcji ${ }^{8}$.

Słusznie przyjmuje się, że nieposzlakowana opinia może być analizowana w dwóch aspektach. Pierwszy ma wymiar natury moralnej i odnosi się do zasad i wartości powszechnie respektowanych w społeczeństwie. Tych wartości i wzorców moralnych pracownik samorządowy nie może nie przestrzegać. Drugi wymiar ma aspekt charakterystyczny dla stanowiska pracownika samorządowego zatrudnionego na stanowisku urzędniczym ${ }^{9}$. Natomiast nieskazitelność charakteru, wymaganą od osoby fizycznej ubiegającej się o zatrudnienie na stanowisku urzędniczym w urzędach państwowych, można określić jako usposobienie człowieka, które nadaje jednolity kierunek jego postępowaniu ${ }^{10}$. Na nieskazitel-

${ }^{5}$ Zgodnie z art. 6. ust. 3 pkt 3 u.p.s. pracownikiem samorządowym zatrudnionym na podstawie umowy o pracę na stanowisku urzędniczym, doradcy lub asystenta może być osoba, która poza spełnieniem innych rygorów określonych w ustawie musi cieszyć się nieposzlakowaną opinią. Natomiast zgodnie z art. 4 pkt 5 u.s.c. w służbie cywilnej może być zatrudniona osoba, która cieszy się nieposzlakowaną opinią.

${ }^{6}$ Zgodnie $\mathrm{z}$ art. 3 pkt 3 u.p.u.p. urzędnikiem państwowym może być osoba, która jest nieskazitelnego charakteru.

${ }^{7}$ Wyrok Sądu Najwyższego z dnia 5 czerwca 2012 r., II PK 263/11, LEX nr 1238101.

${ }^{8}$ Zob. wyrok Naczelnego Sądu Administracyjnego z dnia 18 listopada 1999 r., II SA 1131/99, LEX nr 46696. Zob. też: A. Dubowik, Rygory selekcyjne i nabór do stużby cywilnej $w$ świetle ustawy z 2008 roku, „Praca i Zabezpieczenie Społeczne” 1999, nr 2, s. 16.

${ }^{9}$ H. Szewczyk, Glosa do wyroku SN z 16 października 2009 r., I PK 85/09, LEX nr 140636/1, teza 1; idem, Stosunki pracy..., s. 95.

${ }^{10}$ M. Stych, Krajowa Rada Sądownictwa na tle rozwiązań europejskich, Katowice 2002, s. 68. 
ność charakteru składają się takie cechy osoby pełniącej funkcję publiczną, które kształtują jej społeczny wizerunek. Względem takiej osoby nie mogą toczyć się żadne postępowania czy istnieć okoliczności i zdarzenia, który podważałyby jej wiarygodność i uczciwość ${ }^{11}$. Pojęcie nieskazitelnego charakteru ma szerszy zakres niż pojęcie nieposzlakowanej opinii, które ustawodawca przyjął w u.s.c. i u.p.s. Nieskazitelność charakteru oznacza nie tylko posiadanie cechy, jaką jest nieposzlakowana opinia, ale też obejmuje swoim zakresem nakaz niekaralności osoby, która ma być zatrudniona na stanowisku urzędnika w urzędzie państwowym. Dlatego w pragmatyce służbowej, jaką jest u.p.u.p., brak jest dodatkowego rygoru selekcyjnego nakładającego wymóg niekaralności za przestępstwa umyślne, gdyż obowiązek ten jest zawarty w nieskazitelności charakteru ${ }^{12}$.

Weryfikacja wskazanych rygorów selekcyjnych przez zatrudniającego jest bardzo trudna. Organy rekrutujące osoby mające być zatrudnione na stanowiskach określonych we wskazanych wyżej pragmatykach prawa urzędniczego nie mają instrumentów, przy użyciu których mogłyby sprawdzić, czy kandydaci lub osoby już zatrudnione cieszą się nieposzlakowaną opinią lub nieskazitelnym charakterem. $\mathrm{Z}$ tego powodu jako uwagi de lege ferenda należy zgłaszać konieczność wprowadzenia odpowiednich instrumentów prawnych, które umożliwiłyby rekrutującym weryfikowanie kandydatów na urzędników ${ }^{13}$. Podobnie dokładnie powinny zostać określone zasady weryfikacji pracowników ze względu na to, czy stale realizują oni rygory selekcyjne. Wprowadzenie odpowiednich procedur chroniłoby pracodawcę przed niebezpieczeństwem naruszenia dobra osobistego osoby rekrutowanej lub pracownika, a pracownikowi lub kandydatowi na pracownika gwarantowałoby, że zbierane na jego temat informacje są prawdziwe. Pracownicy byliby też chronieni przed groźbą rozwiązania z nimi stosunku pracy w oparciu o nieprawdziwe informacje na ich temat.

\section{KATEGORIE DÓBR OSOBISTYCH, KTÓRYCH NARUSZENIE MA WPŁYW NA OPINIĘ O OSOBIE PEŁNIĄCEJ FUNKCJĘ PUBLICZNĄ}

W polskim prawie cywilnym nie istnieje zamknięty katalog dóbr osobistych. Przepis art. 23 k.c. wskazuje jedynie przykładowe wyliczenie tych dóbr. Należy przyjąć, że nigdy nie zostanie skonstruowany ich zamknięty katalog. Powstają wciąż nowe kategorie tych dóbr, ponieważ wraz ze zmianą stosunków społecznych jedne dobra osobiste znikają, a inne, podlegające ochronie prawnej, się po-

\footnotetext{
${ }^{11}$ A. Dubowik, Ł. Pisarczyk, Prawo urzędnicze, Warszawa 2011, s. 113-114.

12 J. Stelina, Komentarz do art. 3 ustawy o pracownikach urzędów państwowych, [w:] Prawo urzędnicze. Komentarz, red. K.W. Baran, Warszawa 2014, LEX nr 441249.

${ }^{13}$ Idem, Komentarz do art. 4 ustawy o stużbie cywilnej, [w:] Prawo urzędnicze. Komentarz, LEX nr 441070.
} 
jawiają ${ }^{14}$. Z. Radwański uznał, że „tendencja ta stanowi nie tylko wyraz wzrastającego uznania dla osoby ludzkiej, ale jest zarazem odpowiedzią na mnożące się zagrożenia wywołane rozwojem techniki, a także nieodpowiedzialnym korzystaniem z wolności będącej darem ustroju demokratycznego"15.

Ze względu na to, że w życiu społecznym występuje znaczna ilość dóbr osobistych podlegających ochronie, ocena tego, czy konkretne zdarzenie bądź określona wypowiedź naruszają jakieś dobro musi być dokonana przez sąd po ustaleniu konkretnego stanu faktycznego. Powszechnie przyjmuje się, że dobra osobiste wynikają z wartości niemajątkowych, które ściśle związane są z osobą fizyczną, odnoszą się do jej fizycznej i psychicznej integralności. Mogą być również przejawem jej twórczej działalności. Dobra osobiste wyrażają indywidualność człowieka, jego godność, a nawet jego pozycję wśród innych osób ${ }^{16}$. W odniesieniu do osób publicznych, w tym do osób pełniących funkcje publiczne, najczęstszym przedmiotem spraw o ochronę dóbr osobistych jest ochrona czci, godności, dobrego imienia i prawa do prywatności.

Obecnie w polskim systemie prawnym pojęcie osoby pełniącej funkcję publiczną nie ma jednolitego znaczenia ${ }^{17}$. Dokonując wykładni tego pojęcia, należy odnieść się do wyroków i sporządzonych do nich uzasadnień Trybunału Konstytucyjnego, z których wynika, że osoba pełniąca funkcję publiczną to taki podmiot, który formalnie jest związany z instytucją publiczną, która posiada chociaż w minimalnym zakresie kompetencje decyzyjne w ramach tej instytucji lub też władna jest podejmować takie działania, które będą bezpośrednio kształtowały zakres praw i obowiązków innych osób. Trybunał Konstytucyjny stwierdził, że konkretne i precyzyjne ustalenia, kiedy dokładnie dana osoba związana z określoną instytucją publiczną może być uznana za pełniącą funkcję publiczną nie jest możliwe, gdyż nie każda osoba publiczna pełni funkcję publiczną. Sprawowanie takiej funkcji jest związane $\mathrm{z}$ wykonywaniem określonych zadań $\mathrm{w}$ danym urzędzie, związanych z realizacją władzy publicznej. Chcąc ustalić, czy dana osoba pełni

${ }^{14}$ S. Dmowski, S. Rudnicki, R. Trzaskowski, Kodeks cywilny. Komentarz. Część ogólna, Warszawa 2014, s. 130-131; Kodeks cywilny. Komentarz, red. K. Pietrzykowski, t. 1, Warszawa 2013, s. 97; S. Dmowski, S. Rudnicki, Komentarz do kodeksu cywilnego. Ksiega pierwsza. Część ogólna, Warszawa 2006, s. 97, 99.

${ }^{15}$ Z. Radwański, Prawo cywilne - część ogólna, Warszawa 1997, s. 149.

${ }^{16}$ S. Dmowski, S. Rudnicki, R. Trzaskowski, op. cit., s. 134-135.

${ }^{17}$ Pojęciem tym posługuje się przede wszystkim ustrojodawca w art. 61 ust. 1 Konstytucji RP z dnia 2 kwietnia 1997 r. (Dz.U., nr 78, poz. 483 ze zm.), a także ustawodawca między innymi w art. $115 \S 19$ Kodeksu karnego z dnia 6 czerwca 1997 r. (Dz.U., nr 88, poz. 553) i w art. 5 ust. 2 ustawy o dostępie do informacji publicznej z dnia 6 września 2001 r. (t.j. Dz.U. z 2014 r., poz. 782). Na temat problemów z przyjęciem jednolitej wykładni tego pojęcia zob. J. Uliasz, Osoby petniq̨ce funkcje publiczne też mają prawo do prywatności, s. 3, www.samorzad.lex.pl/czytaj/-/artykyl/ osoby-pelniace-funkce-publiczne-tez-maja-prawo-do-prywatnosci/3 [data dostępu: 22.04.2016]; A. Bobiec, Informacja publiczna a ochrona prywatności osób petniących funkcje publiczne, [w:] Jawność w samorzadzie terytorialnym, red. B. Dolnicki, Warszawa 2015, s. 58-60. 
funkcję publiczną, konieczne jest za każdym razem ustalenie, czy i w jakim zakresie wykonuje ona zadania publiczne właściwe dla instytucji publicznej, z którą jest związana ${ }^{18}$. Naczelny Sąd Administracyjny w orzeczeniu z 2015 r. przyjął natomiast, że osobą pełniącą funkcję publiczną jest każda osoba, która ma wpływ na kształtowanie spraw publicznych $\mathrm{w}$ rozumieniu art. 1 ust. 1 ustawy o dostępie do informacji publicznej, czyli na sferę publiczną ${ }^{19}$.

Dobra osobiste osób fizycznych, w tym osób wykonujących funkcje publiczne, stanowią najistotniejsze ograniczenie swobody dziennikarskiej ${ }^{20}$. Problem związany z konfliktem między wolnością mediów a ochroną dóbr osobistych osób wykonujących funkcję publiczną jest doniosłym, wieloaspektowym zagadnieniem. Jest on często analizowany przez doktrynę, zwłaszcza w aspekcie ochrony prawa do prywatności tych osób ${ }^{21}$. Warto jednak odnieść się do tych zagadnień również w kontekście naruszenia czci, godności i dobrego imienia osób pełniących funkcje publiczne i wskazać, jaki skutek takie naruszenia mogą mieć dla tych podmiotów w aspekcie rękojmi prawidłowego wykonywania powierzonych zadań publicznych w kontekście wskazanych wyżej rygorów selekcyjnych.

Za dobro osobiste art. 23 k.c. uznaje wprost cześć, której dwoma elementami są godność i dobre imię. Godność jest czcią wewnętrzną, natomiast dobre imię to cześć zewnętrzna ${ }^{22}$. Dobra te obejmują wszystkie dziedziny życia prywatnego, zawodowego i społecznego. Naruszenie czci może nastąpić zarówno przez pomówienie o naganne postępowanie w życiu rodzinnym i osobistym, jak i przez przypisanie komuś niewłaściwego zachowania w życiu zawodowym, naruszającego dobre imię danej osoby i mogącego narazić ją na utratę zaufania niezbędnego do wykonywania zawodu czy powierzonej funkcji ${ }^{23}$. Co prawda, osoba publiczna musi się liczyć z nieprzychylnymi dla siebie publikacjami, a także z nie zawsze aprobującymi ocenami jej działalności. Nie oznacza to jednak, że osobom pełniącym funkcje publiczne można bezkarnie zarzucać czyny, których nie popełniły ${ }^{24}$.

${ }^{18}$ Wyrok Trybunału Konstytucyjnego z dnia 11 maja 2007 r., K 2/07, OTK-A 2007, nr 5, poz. 48; wyrok Trybunału Konstytucyjnego z dnia 20 marca 2006 r., K 17/05, OTK-A 2006, nr 3, poz. 30 .

${ }^{19}$ Wyrok Naczelnego Sądu Administracyjnego z dnia 8 lipca 2015 r., I OSK 1530/14, http://czasopismo.legeartis.org/2015/10/osoba-pelniaca-funkcje-publiczna.html [data dostępu: 22.04.2016].

${ }^{20}$ Prawo mediów, red. J. Barta, R. Markiewicz, A. Matlak, Warszawa 2008, s. 461.

${ }^{21} \mathrm{Na}$ ten temat zob. m.in. A. Bobiec, op. cit., s. 65-69; Z. Zawadzka, Wolność prasy a ochrona prywatności osób wykonujących działalność publiczną. Problem rozstrzygania konfliktu zasad, Warszawa 2013, s. 15; I. Zgoliński, Zniesławienie w polskim prawie karnym, Warszawa 2013, s. 216, 224-225; J. Uliasz, op. cit., s. 1-5.

${ }^{22}$ Kodeks cywilny. Komentarz, red. K. Pietrzykowski, t. 1, Warszawa 2013, s. 98-99.

${ }^{23}$ S. Dmowski, S. Rudnicki, R. Trzaskowski, op. cit., s. 136; S. Dmowski, S. Rudnicki, op. cit., s. 100; wyrok Sądu Najwyższego z dnia 8 października 1987 r., II CR 269/87, OSNCP 1989, nr 4, poz. 66.

${ }^{24}$ Wyrok Sądu Apelacyjnego w Gdańsku z dnia 9 października 2014 r., I ACa 310/14, LEX nr 1563497. 
Opinia publiczna ma prawo posiadać wiedzę na temat wykonywania swoich obowiązków przez osoby pełniące funkcje publiczne. Nie ulega wątpliwości, że do opinii społecznej powinien docierać przekaz o patologiach życia publicznego zasługujących na napiętnowanie, ale tylko wówczas, gdy znajduje on oparcie w faktach i zaistniał w rzeczywistości. Nie ma natomiast żadnego uzasadnienia dla zaaprobowania działań polegających na stawianiu tez o nagannych zachowaniach, gdy nie znajdują one uzasadnienia w faktach.

Zgodnie $\mathrm{z}$ art. 6 ust. 1 ustawy - Prawo prasowe prasa jest zobowiązana do prawdziwego przedstawiania omawianych zjawisk ${ }^{25}$. We współczesnym życiu społecznym wszelkie zjawiska tego życia (polityczne, ekonomiczne, prawne) podlegają ocenie. $Z$ tego punktu widzenia szczególnie istotna jest krytyka prasowa, która stanowi publiczną ocenę opartą na konfrontacji określonego stanu faktycznego (rzeczywistego) z przyjętymi założeniami. Celem takiej krytyki jest poszerzenie wiedzy społeczeństwa na dany temat tak, aby obywatele realnie uczestniczyli w rządzeniu państwem, przede wszystkim przez kontrolę społeczną istotnych publicznie spraw. Krytyka prasowa może stymulować dokonywanie wyborów politycznych czy gospodarczych ${ }^{26}$. Granice legalności takiej krytyki ustalił art. 41 prawa prasowego, według którego wytycza je rzetelne i zgodne z zasadami współżycia społecznego przedstawienie krytycznej oceny pracy ${ }^{27}$. Przedmiotem tej krytyki zasadniczo może być tylko publiczna działalność osób wykonujących funkcję publiczną. Powoływanie się na zdarzenia z ich życia prywatnego może mieć miejsce tylko wyjątkowo, gdy okoliczności te mają bezpośredni związek z funkcjami publicznymi pełnionymi przez te osoby ${ }^{28}$.

Wykreowanie (np. przez dziennikarzy) negatywnego obrazu danej osoby publicznej może doprowadzić do podważenia jej pozycji na rynku pracy i może skutecznie zniechęcać do podjęcia z nią jakiejkolwiek współpracy. Ponadto w oczach opinii publicznej taka osoba może zostać wykreowana jako niegodna zaufania i niekompetentna do pełnienia danej funkcji publicznej. Naruszenie czci jest także możliwe przez takie zaprezentowanie faktów i ocen, iż w wyniku ich odpowiedniego powiązania i rozłożenia akcentów całość sugeruje moralnie naganne

${ }^{25}$ Ustawa z dnia 26 stycznia 1984 r. - Prawo prasowe (Dz.U., nr 5, poz. 24 ze zm.). Pojęcie „prawdziwości” rozumie się jako odnoszenie się do informacji o faktach, czyli zdarzeniach mogących być opisanymi jako prawdziwe lub fałszywe. Natomiast oceny negujące lub abstrahujące od istniejącej podstawy faktycznej są sprzeczne z zasadą wyrażoną w art. 6 prawa prasowego. Zob. Prawo prasowe. Komentarz, red. G. Kuczyński, Warszawa 2011, s. 103.

${ }^{26}$ J. Sobczak, Prawo prasowe. Komentarz, Warszawa 2008, s. 283, 289; Prawo prasowe. Komentarz, s. 541.

${ }^{27}$ J. Sobczak, op. cit., s. 292-298, 858-859; wyrok Sądu Najwyższego z dnia 19 czerwca 2015 r., IV CSK 566/14, LEX nr 1793705.

${ }^{28}$ Wyrok Sądu Najwyższego z dnia 28 września 2000 r., V KKN 171/98, OSNKW 2001, nr 3-4, poz. 31 . 
działanie opisywanej postaci ${ }^{29}$. Sąd Najwyższy stwierdził, że w przypadku naruszenia czci należy nie tylko uwzględnić znaczenie słów, ale również kontekst sytuacyjny, w którym zostały użyte ${ }^{30}$. Ponadto przy ocenie naruszenia czci należy mieć na uwadze zarówno subiektywne odczucie osoby żądającej ochrony prawnej, jak i obiektywną reakcję społeczeństwa. Nie można też przy tej ocenie ograniczać się do analizy pewnego zwrotu w abstrakcji, lecz należy zwrot ten wykładać na tle całej wypowiedzi ${ }^{31}$. Naruszenie czci będzie miało miejsce wówczas, gdy można zidentyfikować osobę, która jest adresatem wypowiedzi. W praktyce dziennikarskiej często stosowany jest tzw. kamuflaż, polegający na posłużeniu się jedynie inicjałami danej osoby. Połączenie tych inicjałów ze wskazaniem np. pełnionej funkcji czy zajmowanego stanowiska przez dany podmiot może stanowić wystarczającą wskazówkę do ustalenia przez odbiorców tożsamości osoby, której dotyczą publikowane informacje. Naruszenie czci może nastąpić nie tylko przez użycie sformułowań kategorycznych, ale także przez snucie domysłów, stosowanie pewnych niedomówień, insynuacji czy kierowanie podejrzeń pod czyimś adresem ${ }^{32}$.

Dobrem osobistym, którego naruszenie może wpłynąć negatywnie na opinię o osobie publicznej jest prawo do prywatności. Nie zostało ono co prawda wprost wskazane w art. 23 k.c. jako dobro osobiste, zyskało jednak trwałą pozycję chronionego dobra osobistego w orzecznictwie i dorobku doktryny: ,[...] otwarty katalog dóbr osobistych (art. 23 i 24 k.c.) obejmuje także dobra osobiste związane ze sferą życia prywatnego, w tym prawo do prywatności”33.

Konieczne jest przeprowadzenie linii demarkacyjnej pomiędzy sferą życia prywatnego i rodzinnego z życiem osobistym podlegającym ochronie zgodnie $\mathrm{z}$ art. 47 Konstytucji RP a niewłaściwym zachowaniem i postawą względem innych osób, które świadczy o lekceważeniu norm moralnych i społecznych oraz zasad współżycia społecznego ${ }^{34}$. Fakt pełnienia przez daną osobę funkcji publicznej nie uzasadnia istnienia domniemanej, blankietowej zgody na publikację informacji z jej życia prywatnego. Nie ma przy tym znaczenia - dla oceny same-

${ }^{29}$ Zob. wyrok Sądu Apelacyjnego w Poznaniu z dnia 19 października 1995 r., I ACr 324/95, przytoczony za: E. Nowińska, Wolność wypowiedzi prasowej, Warszawa 2007, s. 142.

${ }^{30}$ Wyrok Sądu Najwyższego z dnia 23 maja 2002 r., IV CKN 1076/00, OSNC 2003, nr 9, poz. 121.

${ }^{31}$ Wyrok Sądu Najwyższego z dnia 16 stycznia 1976 r., II CR 692/75, OSNC 1976, nr 11, poz. 25.

${ }^{32}$ Więcej na ten temat zob. J. Barta, R. Markiewicz, A. Matlak, op. cit., s. 464-466.

${ }^{33}$ Kodeks cywilny. Komentarz, red. K. Pietrzykowski, t. 1, Warszawa 1997, s. 73. Interesujące uwagi na temat ochrony prawa do prywatności pracownika poza miejscem pracy zob. M. Wujczyk, Prawo pracownika do ochrony prywatności, Warszawa 2012, s. 327-335.

${ }^{34}$ Wyrok Naczelnego Sądu Administracyjnego z dnia 18 listopada 1999 r., II SA 1131/99, LEX nr 46696. 
go naruszenia dobra osobistego - czy publikowane informacje są zgodne z prawdą czy nie. Trybunał Konstytucyjny w cytowanym już uzasadnieniu do wyroku w sprawie K 17/05 uznał, że zakres dopuszczalnej informacji o życiu prywatnym osoby pełniącej funkcję publiczną wyznacza uzasadniony interes publiczny. Sąd Najwyższy dodatkowo podkreślił, że ten słuszny interes społeczny nie może być utożsamiany z potrzebą zaspokojenia ciekawości określonego kręgu osób ${ }^{35}$.

\section{ROSZCZENIA SŁUŻĄCE OCHRONIE DÓBR OSOBISTYCH}

W art. $24 \S 1$ k.c. są przewidziane środki ochrony przeciwko naruszeniu dóbr osobistych. Można ich użyć jedynie w sytuacji, gdy naruszenie dobra osobistego jest bezprawne. Przepis jednak statuuje domniemanie bezprawności, które winna obalić osoba dokonująca naruszenia. Zgodnie z obowiązującym systemem prawnym to dokonujący naruszenia, broniąc się $\mathrm{w}$ ewentualnym procesie, powinien za pomocą dowodów wykazać, że np. opisywane przez autora publikacji okoliczności są prawdziwe lub zweryfikowane w sposób zgodny ze standardami przewidzianymi przez prawo prasowe, a rozpowszechnianie zarzutów (dotyczących np. niemoralnego, nielicującego z godnością zachowania) nie przekracza granicy dozwolonej i słusznej krytyki. „Ciężar dowodu braku bezprawności działania (art. 24 k.c.) spoczywa na osobie, której zarzucono naruszenie dobra osobistego; musi ona wykazać, że była do tego uprawniona"36. Przyjmuje się powszechnie, że do okoliczności wyłączających bezprawność naruszenia dobra osobistego należy: działanie w ramach obowiązującego porządku prawnego, zgoda uprawnionego, działanie ze względu na uzasadniony interes społeczny lub jednostkowy ${ }^{37}$. Bezprawność zachowania się w tym przypadku należy rozumieć jako zachowanie się sprzeczne z normami prawa lub zasadami współżycia społecznego, bez względu na winę lub nawet świadomość sprawcy ${ }^{38}$. Pogląd ten w pełni zasługuje na poparcie - czym innym jest bowiem obiektywna bezprawność, istniejąca niezależnie od woli czy wiedzy kogokolwiek (w tym sprawcy), a czym innym wina, czyli subiektywny, wewnętrzny stosunek osoby do czynu. Nie ulega wątpliwości, że osoba publiczna musi mieć świadomość tego, że jako taki podmiot musi się liczyć z nieprzychylnymi dla siebie publikacjami i nie za-

${ }^{35}$ Wyrok Sądu Najwyższego z dnia 11 października 2001 r., II CKN 559/99, OSP 2002, nr 12, poz. 161 .

${ }^{36}$ Uchwała (7) Sądu Najwyższego z dnia 28 maja 1971 r., III PZP 33/70, OSNC 1971, nr 11, poz. 188.

${ }^{37}$ Kodeks cywilny. Komentarz, red. K. Pietrzykowski, t. 1, Warszawa 2002, s. 86; Prawo mediów, s. 484.

${ }^{38}$ Wyrok Sądu Najwyższego z dnia 19 lipca 1982 r., I CR 225/82. 
wsze aprobującymi ocenami jej działalności ${ }^{39}$. Nie oznacza to jednak, że osobom pełniącym funkcje publiczne można bezkarnie zarzucać czyny, których nie popełniły ${ }^{40}$.

Zgodnie z art. $24 \S 1$ k.c. osoba, której dobro osobiste zostało naruszone może żądać by ten, kto dopuścił się naruszenia, dopełnił czynności potrzebnych do usunięcia jego skutków. Jest to podstawa do żądania przez osobę, której dobra osobiste zostały naruszone, aby sąd nakazał naruszającemu te dobra zachowanie mające na celu usunięcie skutków naruszenia dóbr osobistych. Zachowanie to może polegać na publikacji odpowiednich oświadczeń oraz zapłacie zadośćuczynienia. Art. $24 \S 1$ k.c. wprost przewiduje możliwość żądania złożenia oświadczenia, a zatem należy przyjąć, że ewentualny spór może dotyczyć jedynie formy, w jakiej ma ono zostać złożone, nie może natomiast dotyczyć samego żądania.

W doktrynie i orzecznictwie zostało przyjęte, iż środki ochrony oraz sposób ochrony w sprawach o naruszenie dóbr osobistych mają być adekwatne do naruszenia ${ }^{41}$. Trybunał Konstytucyjny w orzeczeniu z dnia 12 maja 2008 r. stwierdził, że podnoszenie lub rozgłaszanie zarzutów dotyczących osób pełniących funkcje publiczne, które mogą narazić je na zniesławienie, służy społecznie uzasadnionemu interesowi, ale tylko jeśli zarzuty te są prawdziwe ${ }^{42}$. Ponadto - zgodnie z poglądem wyrażonym przez Sąd Najwyższy w uchwale z dnia 18 lutego 2005 r. - publikacja nieprawdziwych zarzutów musi się wiązać z powstaniem obowiązku ich odwołania ${ }^{43}$.

Granicę wolności wypowiedzi w debacie publicznej zawsze przekraczają wypowiedzi (publikacje) przedstawiające nieprawdziwe informacje o osobach pełniących funkcje publiczne oraz zawierające opinie, które nie mają wystarczającego oparcia w faktach ${ }^{44}$.

${ }^{39}$ Wyrok Sądu Najwyższego z dnia 23 lipca 2015 r., I CSK 548/14, LEX nr 1781844; wyrok Sądu Apelacyjnego w Warszawie z dnia 23 czerwca 2015 r., VI ACa 1460/14, LEX nr 1814839.

${ }^{40}$ Wyrok Sądu Apelacyjnego w Gdańsku z dnia 9 października 2014 r., I ACa 310/14, http:// orzeczenia.gdansk.sa.gov.pl/content/\$N/151000000000503_I_ACa_000310_2014_Uz_2014-1009_001 [data dostępu: 03.05.2016].

${ }^{41}$ Wyrok Sądu Apelacyjnego w Lublinie z dnia 10 lipca 1998 r., I ACa 202/98, OSA 2000, nr 2, poz. 6.

${ }^{42}$ Wyrok Trybunału Konstytucyjnego z dnia 12 maja 2008 r., SK 43/05, OTK-A 2008, nr 4, poz. 57.

${ }^{43}$ Uchwała Sądu Najwyższego z dnia 18 lutego 2005 r., III CZP 53/04, OSN 2005, nr 7-8, poz. 114.

${ }^{44}$ Wyrok Sądu Najwyższego z dnia 25 lutego 2010 r., I CSK 220/09, LEX nr 583722. Warto w tym miejscu przytoczyć także wyrok Sądu Apelacyjnego w Warszawie z dnia 21 maja 2013 r., I ACa 1341/12 (niepublik.): ,[...] dla zrealizowania przesłanki rzeczywistego usunięcia skutków naruszenia dóbr osobistych powoda, oświadczenie o jego przeproszeniu powinno mieć taki sam potencjalny zasięg oddziaływania jak inkryminowana wypowiedź, co oznacza także uwzględnienie przedmiotowej adekwatności brzmienia oświadczenia o przeproszeniu do sposobu naruszenia dobra 
Powszechna dostępność Internetu i możliwość korzystania z różnych wyszukiwarek internetowych powoduje, że każda osoba może w dowolnym czasie i miejscu zapoznać się z określonymi informacjami, budując na ich podstawie swój osąd na temat danej osoby, co często powoduje wzmocnienie skutków naruszenia dóbr osobistych osoby publicznej. $Z$ tego powodu uzasadnione jest kierowanie żądania o publikację przeprosin w odpowiedniej formie również na stronach internetowych. Roszczenie takie znajduje uzasadnienie w brzmieniu i celu art. 24 k.c. Ponadto osoba publiczna, której dobra osobiste zostały naruszone, może domagać się odpowiedniego zadośćuczynienia za doznaną krzywdę. Roszczenie to jest oparte na art. 24 k.c. w zw. z art. 448 k.c. Do przesłanek jego uwzględnienia należy naruszenie dobra osobistego, bezprawność zachowania, krzywda wynikająca z naruszenia dobra oraz wina naruszyciela (przy czym za wystarczający uznaje się najlżejszy stopień winy culpa levissima $)^{45}$. Dochodzona tytułem zadośćuczynienia kwota winna w sposób godny zadośćuczynić poczuciu publicznego upokorzenia i niszczenia dobrego imienia osoby pełniącej funkcję publiczną. Krzywda nie jest jedynym kryterium uzasadniającym zastosowanie zadośćuczynienia. Zadośćuczynienie pieniężne $\mathrm{w}$ takich sprawach powinno spełniać także funkcję prewencyjną ${ }^{46}$, dlatego jego wysokość powinna uwzględniać sytuację majątkową osoby odpowiedzialnej, a nie koncentrować się wyłącznie na kompensacji uszczerbku niemajątkowego osoby pokrzywdzonej. W szczególności w odniesieniu do wydawcy publikującego nieprawdziwe informacje relatywnie niska wysokość zasądzonego zadośćuczynienia, które stanowiłoby tylko „symboliczną”, a nie rzeczywistą wielkość kalkulacyjną w jego działalności gospodarczej, nie wywołałoby efektu „tamującego”, zapobiegającego dokonywaniu w przyszłości naruszeń dóbr osobistych ${ }^{47}$.

Niezależnie od skorzystania ze wskazanych wyżej środków, których celem jest usunięcie skutków naruszenia dobra osobistego, osoba uprawniona może także żądać zapłaty odpowiedniej kwoty pieniężnej na wskazany cel społeczny.

Ponadto osoba publiczna, której dobra osobiste zostały naruszone (np. w wyniku publikacji prasowej), może wystąpić do sądu z wnioskiem o udzielenie zabezpieczenia na podstawie art. $730 \S 1$ k.p.c. Warunki udzielenia takiego zabezpieczenia określa art. $730^{1}$ k.p.c. Zgodnie $\mathrm{z}$ treścią tego przepisu niezbędne jest

osobistego". O przesłance rzeczywistego usunięcia skutków naruszenia w podobnym tonie wypowiedział się T. Targosz, [w:] Media a dobra osobiste, red. J. Barta, R. Markiewicz, Warszawa 2009, s. 321.

${ }^{45}$ Media a dobra osobiste, s. 348 i n.

${ }^{46}$ Wyrok Sądu Apelacyjnego w Katowicach z dnia 21 października 2015 r., I ACa 520/15, LEX nr 1927449.

${ }^{47}$ Wyrok Sądu Apelacyjnego w Krakowie z dnia 5 listopada 2002 r., I ACa 869/02, TPP 2003, nr 3, poz. 109. 
uprawdopodobnienie istnienia roszczenia i interesu prawnego. Wymóg uprawdopodobnienia roszczenia oznacza konieczność uprawdopodobnienia faktów, z których jest ono wywodzone ${ }^{48}$.

\section{SKUTKI NARUSZENIA DÓBR OSOBISTYCH OSOBY PEŁNIĄCEJ FUNKCJĘ PUBLICZNĄ}

Poza dochodzeniem ochrony dóbr osobistych na gruncie prawa cywilnego, osoba pełniąca funkcję publiczną może w celu ochrony czci podnieść również zarzut zniesławienia wobec dziennikarza, który względem niej postawił zarzut zniesławiający oparty na nieprawdziwych faktach.

Część doktryny uważa, że takie działanie dziennikarza zawsze jest nielegal$n e^{49}$. Trybunał Konstytucyjny stwierdził, że żaden obywatel nie ma obowiązku ubiegać się o pełnienie funkcji publicznej, a zatem podejmując się jej wykonywania, musi godzić się z następstwami swojej decyzji, które polegają również na upublicznieniu pewnych informacji z życia prywatnego ${ }^{50}$. Osoby sprawujące funkcję publiczną muszą zatem liczyć się z krytyką, często brutalną, jednak pomimo sprawowania funkcji publicznej mają prawo do uzyskania ochrony prawnej przed nieprawdziwymi zarzutami odnoszącymi się do faktów ${ }^{51}$. Wobec osób wykonujących funkcję publiczną podwyższony jest próg tolerancji dla ostrości ocen wyrażanych w mediach wobec ich działań. Fakt podwyższenia tego progu nie powinien usuwać wymagania prawdziwości zarzutów, na których opiera się krytyka $^{52}$. W granicach wolności wypowiedzi i dopuszczalnej krytyki nie mieści się nieskrępowana i nielicząca się z realiami dowolność w zniesławieniu ${ }^{53}$. Niestety, stanowisko judykatury w tym zakresie nie jest tak jednoznaczne: ,[...] wykazanie przez dziennikarza, że przy zbieraniu i wykorzystaniu materiałów prasowych działał w obronie społecznie uzasadnionego interesu oraz wypełnił obowiązek zachowania szczególnej staranności i rzetelności, uchyla bezprawność dziennikarza. Jeżeli zarzut okaże się nieprawdziwy, dziennikarz zobowiązany jest do

${ }^{48}$ Kodeks postepowania cywilnego. Komentarz, red. A. Jakubecki, Warszawa 2008, s. 1021.

${ }^{49}$ Kodeks cywilny. Komentarz, red. K. Pietrzykowski, t. 1, Warszawa 2013, s. 100-101; J. Barta, R. Markiewicz, Bezprawność naruszenia dobra osobistego wobec rozpowszechnienia w prawie nieprawdziwych informacji, [w:] Rozprawy prawnicze. Księga pamiatkowa Profesora Maksymiliana Pazdana, red. L. Ogiegło, W. Popiołek, M. Szpunar, Kraków 2005, s. 796.

${ }^{50}$ Wyrok Trybunału Konstytucyjnego z dnia 21 października 1998 r., K 24/98, OTK 1998, nr 6, poz. 97.

${ }^{51}$ Wyrok Sądu Apelacyjnego w Poznaniu z dnia 9 lutego 2012 r., I ACa 1163/11, LEX nr 1133338.

${ }^{52}$ Kodeks cywilny. Komentarz, red. K. Pietrzykowski, t. 1, Warszawa 2013, s. 101.

${ }^{53}$ I. Zgoliński, op. cit., s. 216. 
jego odwołania"54. Oznacza to, że nawet jeśli dziennikarz oprze się na materiale zawierającym nieprawdziwe informacje, a wykaże się starannością przy ich zbieraniu i wykorzystaniu, to nie będzie według sądu działał bezprawnie. Słusznie zatem stawia się pytanie o podstawę prawną, w oparciu o którą można by żądać od niego odwołania poczynionych zarzutów względem osoby wykonującej funkcję publiczną, skoro sąd przyjmuje, że jego działanie nie było bezprawne ${ }^{55}$.

Mając na uwadze powyższy zakres możliwości naruszenia dóbr osobistych osób pełniących funkcje publiczne w środkach masowego przekazu i przysługującą im ochronę oraz uwzględniając fakt, że brak jest w pragmatykach prawa urzędniczego mierników, według których podmiot zatrudniający dokonywałby oceny, czy doszło do utraty wskazanych rygorów, można dostrzec niebezpieczny, bezpośredni związek pomiędzy rozpowszechnieniem na temat danej osoby nieprawdziwych informacji kreujących jej wizerunek a decyzją podmiotu zatrudniającego o rozwiązaniu z nią stosunku zatrudnienia ze względu na utratę rygoru selekcyjnego. Podane w mediach wiadomości mogą wydawać się wiarygodne, zwłaszcza że z prawa prasowego i etyki dziennikarskiej wynika, że dziennikarze powinni opierać się tylko na odpowiednio sprawdzonych i prawdziwych informacjach. $\mathrm{Z}$ jednej strony czyniąc takie założenie i uwzględniając presję społeczną (zarzuty stawiane osobie pełniącej funkcję publiczną mogą bowiem być bardzo poważne), a z drugiej strony nie mając żadnych ustawowych wytycznych, którymi musiałby się kierować przełożony, dokonując oceny analizowanych rygorów selekcyjnych, pracodawca może rozwiązać $\mathrm{z}$ daną osobą stosunek pracy, nie czekając na prawomocne zakończenie postępowań wszczętych z tytułu naruszenia dóbr osobistych.

\section{PODSUMOWANIE}

Wskazane w pragmatykach prawa urzędniczego rygory selekcyjne nieskazitelności charakteru i nieposzlakowanej opinii mają zagwarantować rękojmię należytego wykonywania obowiązków zawodowych przez osoby zatrudnione na wskazanych w tych aktach prawnych stanowiskach. W przypadku utraty nieposzlakowanej opinii przez pracownika samorządowego zatrudnionego na stanowisku urzędniczym lub członka korpusu służby cywilnej na podstawie umowy o pracę istnieje konieczność rozwiązania z nimi stosunku pracy ${ }^{56}$. Podobnie z tych samych przyczyn dojdzie do ustania stosunku pracy z mianowania ${ }^{57}$. Analogiczne zasady odnoszą się do pracowników urzędów państwowych. $\mathrm{Z}$ jednej strony

${ }^{54}$ Uchwała (7) Sądu Najwyższego z dnia 18 lutego 2005 r., III CZP 53/04, OSN 2005, nr 7-8, poz. 114; wyrok Sądu Najwyższego z dnia 14 maja 2005 r., I CKN 463/01, OSP 2004, nr 2, poz. 22.

${ }^{55}$ Kodeks cywilny. Komentarz, red. K. Pietrzykowski, t. 1, Warszawa 2013, s. 101.

${ }^{56}$ Wyrok Sądu Najwyższego z dnia 16 października 2009 r. I PK 85/09, OSNP 2011, nr 11-12, poz. 146; wyrok Sądu Najwyższego z dnia 15 marca 2011 r., I PK 192/10, LEX nr 1162172; wyrok Sądu Najwyższego z dnia 8 sierpnia 2013 r., I PK 59/13, „Gazeta Prawna” 2013/250/8.

${ }^{57}$ H. Szewczyk, Stosunki pracy..., s. 97-100. 
wobec bardzo cennego i mało konkretnego pojęcia, jakim jest nieposzlakowana opinia i nieskazitelny charakter, a z drugiej strony - powagi skutków utraty przez pracownika zdolności do wykazania się wypełnianiem tych rygorów, należy postulować wprowadzenie stosownych regulacji, które zagwarantują pracownikom, że zatrudniający będzie związany tymi konkretnymi regulacjami przy dokonywaniu weryfikacji okoliczności mających wpływ na ustalenie, czy pracownik spełnia wymogi zawarte w rygorach selekcyjnych. W przeciwnym razie może dochodzić do bezprawnych rozwiązań stosunków pracy. Jest to szczególnie zauważalne w związku z osobami pełniącymi funkcje publiczne, które są narażone na krytykę prasową. W wyniku nierzetelnej krytyki urzędnik może zostać wykreowany przez dziennikarzy na osobę niegodną zaufania, niemoralną czy niekompetentną do pełnienia funkcji publicznej. Brak ustawowych kryteriów, według których pracodawca jest zobowiązany dokonywać weryfikacji tego typu informacji, z jednocześnie mocno ocennym charakterem rygoru nieskazitelności charakteru i nieposzlakowanej opinii, może doprowadzić do krzywdzącego rozstrzygnięcia pracowniczego dla osoby pełniącej funkcję publiczną, czyli do rozwiązania z nią stosunku pracy.

Należy zauważyć, że brak stosownych rozwiązań prawnych w tym zakresie jest niekorzystny nie tylko dla pracownika, ale również dla pracodawcy, gdyż pracownik, z którym zostanie rozwiązany stosunek pracy ze względu na niespełnienie przez niego wskazanych rygorów selekcyjnych, może wystąpić przeciw pracodawcy z powództwem z tytułu naruszenia dóbr osobistych, jeśli uzna, że ten oparł się na nieprawdziwych informacjach na jego temat i nie zbadał wystarczająco zasadności i prawdziwości wykreowanych np. w prasie i Internecie informacji na jego temat, czym doprowadził do krzywdzącej pracownika dyskwalifikacji zawodowej ${ }^{58}$. W konsekwencji może on nie tylko być przywrócony do pracy, ale też może podnieść roszczenia z tytułu dyskryminacji.

Pracodawca ma obecnie formalnie dużą swobodę w zakresie dokonywania oceny, przy uwzględnieniu, że zarówno nieskazitelność charakteru, jak i nieposzlakowana opinia są przesłankami o charakterze nieostrym. Należy dlatego de lege ferenda postulować przyjęcie takich rozwiązań prawnych, które wyraźnie określą zasady postępowania przy dokonywaniu przez pracodawcę oceny, czy pracownik utracił nieposzlakowaną opinię lub nieskazitelny charakter.

\section{BIBLIOGRAFIA}

Barta J., Markiewicz R., Bezprawność naruszenia dobra osobistego wobec rozpowszechnienia w prawie nieprawdziwych informacji, [w:] Rozprawy prawnicze. Ksiegga pamiatkowa Profesora Maksymiliana Pazdana, red. L. Ogiegło, W. Popiołek, M. Szpunar, Kraków 2005.

${ }^{58}$ Zgodnie $\mathrm{z}$ art. $11^{1}$ k.p. pracodawca jest obowiązany szanować godność i inne dobra osobiste pracownika. 
Bobiec A., Informacja publiczna a ochrona prywatności osób petniących funkcje publiczne, [w:] Jawność w samorzadzie terytorialnym, red. B. Dolnicki, Warszawa 2015.

Dmowski S., Rudnicki S., Komentarz do kodeksu cywilnego. Księga pierwsza. Część ogólna, Warszawa 2006.

Dmowski S., Rudnicki S., Trzaskowski R., Kodeks cywilny. Komentarz. Część ogólna, Warszawa 2014.

Dubowik A., Rygory selekcyjne i nabór do stużby cywilnej w świetle ustawy z 2008 roku, „Praca i Zabezpieczenie Społeczne" 1999, nr 2.

Dubowik A., Pisarczyk Ł., Prawo urzędnicze, Warszawa 2011.

Kodeks cywilny. Komentarz, red. K. Pietrzykowski, t. 1, Warszawa 1997.

Kodeks cywilny. Komentarz, red. K. Pietrzykowski, t. 1, Warszawa 2002.

Kodeks cywilny. Komentarz, red. K. Pietrzykowski, t. 1, Warszawa 2013.

Kodeks postępowania cywilnego. Komentarz, red. A. Jakubecki, Warszawa 2008.

Konstytucja RP z dnia 2 kwietnia 1997 r. (Dz.U., nr 78, poz. 483 ze zm.).

Media a dobra osobiste, red. J. Barta, R. Markiewicz, Warszawa 2009.

Nowińska E., Wolność wypowiedzi prasowej, Warszawa 2007.

Prawo mediów, red. J. Barta, R. Markiewicz, A. Matlak, Warszawa 2008.

Prawo prasowe. Komentarz, red. G. Kuczyński, Warszawa 2011.

Radwański Z., Prawo cywilne - część ogólna, Warszawa 1997.

Sobczak J., Prawo prasowe. Komentarz, Warszawa 2008.

Stelina J., Komentarz do art. 3 ustawy o pracownikach urzędów państwowych, [w:] Prawo urzędnicze. Komentarz, red. K.W. Baran, Warszawa 2014.

Stelina J., Komentarz do art. 4 ustawy o stużbie cywilnej, [w:] Prawo urzędnicze. Komentarz, red. K.W. Baran, Warszawa 2014.

Stych M., Krajowa Rada Sadownictwa na tle rozwiazań europejskich, Katowice 2002.

Szewczyk H., Glosa do wyroku SN z 16 października 2009 r., I PK 85/09, LEX nr 140636/1.

Szewczyk H., Stosunki pracy w samorzadzie terytorialnym, Warszawa 2012.

Targosz T., [w:] Media a dobra osobiste, red. J. Barta, R. Markiewicz, Warszawa 2009.

Uchwała (7) Sądu Najwyższego z dnia 28 maja 1971 r., III PZP 33/70, OSNC 1971, nr 11, poz. 188.

Uchwała (7) Sądu Najwyższego z dnia 18 lutego 2005 r., III CZP 53/04, OSN 2005, nr 7-8, poz. 114.

Uliasz J., Osoby petniace funkcje publiczne też maja prawo do prywatności, www.samorzad.lex. $\mathrm{pl} /$ czytaj/-/artykyl/osoby-pelniace-funkce-publiczne-tez-maja-prawo-do-prywatnosci/3 [data dostępu: 22.04.2016].

Ustawa o pracownikach samorządowych z dnia 21 listopada 2008 r. (t.j. Dz.U. z 2014 r., poz. 1202).

Ustawa o pracownikach urzędów państwowych z dnia 16 września 1982 r. (t.j. Dz.U. z 2013 r., poz. 269).

Ustawa o służbie cywilnej z dnia 21 listopada 2008 r. (t.j. Dz.U. z 2014 r., poz. 1111).

Ustawa z dnia 26 stycznia 1984 r. - Prawo prasowe (Dz.U., nr 5, poz. 24 ze zm.).

Wujczyk M., Prawo pracownika do ochrony prywatności, Warszawa 2012.

Wyrok Naczelnego Sądu Administracyjnego z dnia 18 listopada 1999 r., II SA 1131/99, LEX nr 46696.

Wyrok Naczelnego Sądu Administracyjnego z dnia 8 lipca 2015 r., I OSK 1530/14, http://czasopismo.legeartis.org/2015/10/osoba-pelniaca-funkcje-publiczna.html [data dostępu: 22.04.2016]

Wyrok Sądu Apelacyjnego w Gdańsku z dnia 9 października 2014 r., I ACa 310/14, LEX nr 1563497.

Wyrok Sądu Apelacyjnego w Katowicach z dnia 21 października 2015 r., I ACa 520/15, LEX nr 1927449.

Wyrok Sądu Apelacyjnego w Krakowie z dnia 5 listopada 2002 r., I ACa 869/02, TPP 2003, nr 3, poz. 109. 
Wyrok Sądu Apelacyjnego w Lublinie z dnia 10 lipca 1998 r., I ACa 202/98, OSA 2000, nr 2, poz. 6. Wyrok Sądu Apelacyjnego w Poznaniu z dnia 9 lutego 2012 r., I ACa 1163/11, LEX nr 1133338. Wyrok Sądu Apelacyjnego w Warszawie z dnia 21 maja 2013 r., I ACa 1341/12 (niepublik.). Wyrok Sądu Apelacyjnego w Warszawie z dnia 23 czerwca 2015 r., VI ACa 1460/14, LEX nr 1814839.

Wyrok Sądu Najwyższego z dnia 16 stycznia 1976 r., II CR 692/75, OSNC 1976, nr 11, poz. 25. Wyrok Sądu Najwyższego z dnia 19 lipca 1982 r., I CR 225/82.

Wyrok Sądu Najwyższego z dnia 8 października 1987 r., II CR 269/87, OSNCP 1989, nr 4, poz. 66.

Wyrok Sądu Najwyższego z dnia 28 września 2000 r., V KKN 171/98, OSNKW 2001, nr 3-4, poz. 31.

Wyrok Sądu Najwyższego z dnia 11 października 2001 r., II CKN 559/99, OSP 2002, nr 12, poz. 161 .

Wyrok Sądu Najwyższego z dnia 23 maja 2002 r., IV CKN 1076/00, OSNC 2003, nr 9, poz. 121.

Wyrok Sądu Najwyższego z dnia 14 maja 2005 r., I CKN 463/01, OSP 2004, nr 2, poz. 22.

Wyrok Sądu Najwyższego z dnia 16 października 2009 r. I PK 85/09, OSNP 2011, nr 11-12, poz. 146.

Wyrok Sądu Najwyższego z dnia 25 lutego 2010 r., I CSK 220/09, LEX nr 583722.

Wyrok Sądu Najwyższego z dnia 15 marca 2011 r., I PK 192/10, LEX nr 1162172.

Wyrok Sądu Najwyższego z dnia 5 czerwca 2012 r., II PK 263/11, LEX nr 1238101.

Wyrok Sądu Najwyższego z dnia 8 sierpnia 2013 r., I PK 59/13, „Gazeta Prawna” 2013/250/8.

Wyrok Sądu Najwyższego z dnia 19 czerwca 2015 r., IV CSK 566/14, LEX nr 1793705.

Wyrok Sądu Najwyższego z dnia 23 lipca 2015 r., I CSK 548/14, LEX nr 1781844.

Wyrok Trybunału Konstytucyjnego z dnia 21 października 1998 r., K 24/98, OTK 1998, nr 6, poz. 97.

Wyrok Trybunału Konstytucyjnego z dnia 20 marca 2006 r., K 17/05, OTK-A 2006, nr 3, poz. 30. Wyrok Trybunału Konstytucyjnego z dnia 11 maja 2007 r., K 2/07, OTK-A 2007, nr 5, poz. 48. Wyrok Trybunału Konstytucyjnego z dnia 12 maja 2008 r., SK 43/05, OTK-A 2008, nr 4, poz. 57. Zawadzka Z., Wolność prasy a ochrona prywatności osób wykonujących działalność publiczną. Problem rozstrzygania konfliktu zasad, Warszawa 2013.

Zgoliński I., Zniesławienie w polskim prawie karnym, Warszawa 2013.

\section{SUMMARY}

This article is to prove that under the existing law creation of the public image of the civil servants may influence their atitude to employment relationship. The legislator did not point to any objective criteria which should be used to evaluate if a given person meets selection limits regarding unspotted character and flawless reputation. Thus personal rights are in relations with defined selection limits. In the article basic categories of personal rights whose infringement may influence evaluation of a public figure are presented. It is also shown what the protection of personal rights means and what kinds of claims a public figure whose personal rights have been infringed can have. Additionally, the influence of the infringement of personal rights may have on the person's employment is discussed.

Keywords: civil servants; employee; employment; selection limits; personal rights 